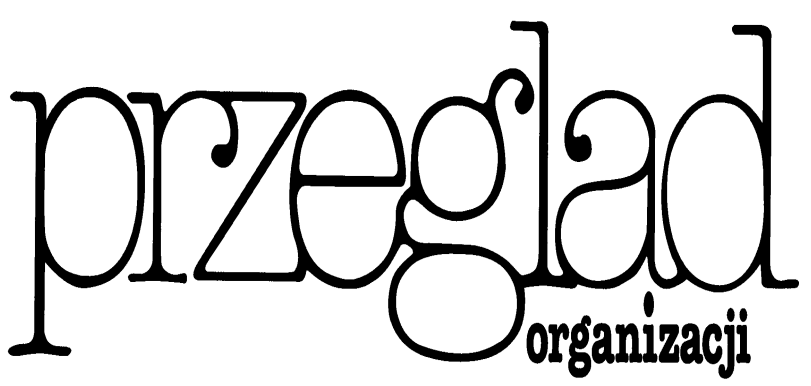

Uwzględnienie zarządzania ryzykiem w organizacji sprzedaży energii elektrycznej

https://doi.org/10.33141/po.2005.78.07

\title{
Dariusz Michalski
}

Przegląd Organizacji, Nr 7/8 (786/787), 2005, ss. 29-32 www.przegladorganizacji.pl Towarzystwo Naukowe Organizacji i Kierownictwa (TNOiK)

Istnieje wiele sposobów na stworzenie trwałej przewagi konkurencyjnej na rynku energii elektrycznej. Jednak każdy z dostępnych wariantów łączy się nierozerwalnie ze zbudowaniem wizerunku wiarygodnego kontrahenta, zapewnieniem niskiego kosztu finansowania działalności operacyjnej oraz ustabilizowaniem przyszłych wyników finansowych. Każdy z wymienionych aspektów nieodłącznie związany jest $\mathrm{z}$ pojęciem ryzyka i koniecznością zarządzania nim, a ponieważ handel energia elektryczna w warunkach wolnego rynku energii należy do jednych z najbardziej ryzykownych działalności, należy w przypadku przedsiębiorstw elektroenergetycznych zwrócić szczególną uwagę na aspekt zarządzania ryzykiem w trakcie realizacji dostaw energii elektrycznej.

Należy zadać pytanie, czy potencjalny kontrahent jest przygotowany do zabezpieczenia nie zakłóconych dostaw energii elektrycznej oraz czy zmiany sytuacji na rynku energii i w gospodarce nie wpłyna negatywnie na możliwość wywiązywania się przez niego ze zobowiązań kontraktowych. Klienci powinni rozważyć już na etapie przygotowywania swoich strategii biznesowych, jaką wartość niesie ze sobą współpraca z wiarygodnym i solidnym kontrahentem. A jakie mogą być koszty zawierania kontraktów z firmą, która nie zarządza świadomie ryzykiem swojej działalności.

Funkcjonowanie dostawców energii elektrycznej w warunkach konkurencji jest narażone na tak znaczne ryzyko, że otrzymany obraz, będący odpowiedzią na pytania dotyczace jedynie prawdopodobnych zagrożeń oraz wywołanych przez nie strat finansowych, może nie oddawać całości zagrożeń. Części z nich nawet nie jesteśmy w stanie wcześniej przewidzieć. Dodatkowo mogą się one wzajemnie przenikać. Świadomość tego skłania do zadawania tych samych pytań w odmienny sposób:

- czego przedsiębiorstwo może być pewne,

- jakie procesy biznesowe sa pewne,

- gdzie kończy się pewność i zaczyna ryzyko? 
Określenie tego, co pewne oraz obszaru ryzyka tworzy dopiero całościowy obraz położenia przedsiębiorstwa na rynku energii elektrycznej. Dużą rolę $\mathrm{w}$ tym procesie odgrywają narzędzia wspierające szacowanie niepewności. Niestety, na rynek energii elektrycznej nie można w prosty sposób przenieść rozwiązań sprawdzonych na innych rynkach. Narzędzia mające wspomóc kierownictwo w podejmowaniu decyzji muszą być dostosowane do indywidualnej specyfiki tego rynku oraz nowej roli energii elektrycznej, stającej się na wolnym rynku towarem, który jednak ze względu na swoją charakterystykę wywołuje znaczne ryzyko dla wszystkich jego uczestników.

W takiej sytuacji kluczowego znaczenia nabiera właściwa organizacja procesu akceptacji, zawierania i rozliczania transakcji sprzedaży energii elektrycznej. Powinna ona umożliwić analizę ryzyka jeszcze przed wykonaniem transakcji. Dodatkowo należy tak zaprojektować ten proces, aby zneutralizować negatywny wpływ ryzyka na rentowność transakcji.

\section{Elementy procesu realizowania transakcji na konkurencyjnym rynku energii elektrycznej}

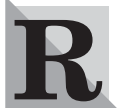

ealizacja transakcji na rynku energii elektrycznej może zostać podzielona na cztery etapy: zawieranie, $\bullet$ zatwierdzanie, $\bullet$ zarządzanie ryzykiem, $\bullet$ rozliczanie i księgowanie transakcji.

Jednak przed rozpoczęciem jakiejkolwiek działalności handlowej kierownictwo przedsiębiorstwa i front office muszą wypracować strategię rozwoju działalności biznesowej, będącą w zgodzie z polityką zarządzania ryzykiem i określonym profilem relacji planowanego wyniku finansowego i podejmowanego ryzyka. Front office powinien codziennie analizować swoją pozycję rynkową (poprzez identyfikację i analizę wszystkich otwartych pozycji) oraz szacować poziom ryzyka rynkowego i kredytowego.

Kontrakty, charakteryzujące się znacznym skomplikowaniem lub długim okresem trwania, mogą wymagać dodatkowych analiz, celem określenia ich rzeczywistej wartości rynkowej ${ }^{11}$. Jeżeli przygotowywana transakcja wykracza poza ramy standardowych kontraktów, do jej zawarcia konieczne jest przeprowadzenie dodatkowych analiz, celem uzyskania akceptacji middle i back office oraz zarządzania ryzykiem. Służby uczestniczące w jej realizacji powinny spotkać się, aby przedyskutować transakcję i w pełni zrozumieć jej konstrukcję oraz wypracować sposób jej oceny ${ }^{2}$. Wycena wartości rynkowej (tzw. mark-to-market) transakcji zostaje przeprowadzona na podstawie aktualnych danych rynkowych i przyjętych założeń. Dane te sa wprowadzane do modelu, zbudowanego na podstawie założeń dotyczących kosztów ryzyka operacyjnego, płynności rynku oraz ryzyka rynkowego.

Innym zadaniem jest przygotowanie profilu ryzyka dla każdego produktu i każdej lokalizacji transakcji (jeżeli są one przeprowadzane na różnych rynkach). Powinien on brać pod uwagę informacje nie tylko o przewidywanych cenach ${ }^{3)}$, ale również o ich zmienności. Krzywa cen forward jest dzielona zwykle na dwa okresy:

- okres notowany na rynku;
- okres analizowany oparty na prognozie cenowej przygotowanej na podstawie analizy fundamentalnej rynku i technik prognostycznych.

Wszystkie wartości cen i zmienności przygotowane przez front office powinny być ocenione i akceptowane przez służby middle office.

Logistyka kontraktu sprzedaży energii elektrycznej jest ściśle powiązana z grafikowaniem fizycznego przepływu energii z punktu A do punktu B. Aby to wykonać, osoba przygotowująca grafiki powinna uzyskać wszystkie niezbędne informacje przedstawiające pozycję przedsiębiorstwa dla każdego okresu rozliczeniowego (np. 1 godziny) dla każdego: $\bullet$ produktu, - miejsca poboru, - dostawy energii, - czasu jej trwania.

$\mathrm{Na}$ ich podstawie określa się ilości i lokalizacje, które powinny znaleźć się w grafiku. Jeżeli ryzyko wolumenu ${ }^{4)}$ jest ponoszone przez dostawcę, dodatkowo powinien zostać zaprognozowany popyt jego klientów.

W przypadku możliwości wystąpienia ograniczeń przesyłowych lub konieczności wzięcia udziału w aukcjach na zdolności przesyłowe przygotowujący grafiki powinien również dokonać analizy najkorzystniejszej trasy przesyłu energii. W przypadku wystapienia jakichkolwiek zagrożeń dla realizacji kontraktu (np. braku możliwości przesyłu energii), przygotowujący grafik powinien niezwłocznie skontaktować się z osobą, która go zawarła.

\section{Miejsce zarządzania ryzykiem w realizacji transakcji na rynku energii elektrycznej}

$\mathbf{K}$

luczowym zagadnieniem dla skutecznego zarządzania ryzykiem w czasie realizacji sprzedaży energii elektrycznej jest wdrożenie procedury zatwierdzania transakcji. Może być ona podzielone na trzy podstawowe kategorie: $\bullet$ zatwierdzanie struktury transakcji ${ }^{5)}$, o ocena, $\bullet$ akceptacja.

W trakcie przygotowywania struktury transakcji middle office jest odpowiedzialne za przegląd warunków i konstrukcji kontraktów oraz sprawdzenie poprawności przyjętych założeń. W tym samym czasie następują też identyfikacja i kwantyfikowanie ryzyk.

Ocena transakcji zostaje przeprowadzona przed wprowadzeniem kontraktu do systemu handlowego. Realizują ją niezależnie od siebie front i middle office: - front office powinien przeprowadzić analizę zgodności posiadanych danych $\mathrm{z}$ systemem handlowym oraz potwierdzić ich poprawność;

- middle office powinien sprawdzić poprawność analiz przeprowadzonych w front office i przeprowadzić własne badanie zgodności danych.

Podwójne zbadanie poprawności danych umożliwia uniknięcia błędów w oszacowaniu ryzyka, które mogą zostać $\mathrm{w}$ przeciwnym razie zidentyfikowane dopiero w momencie wykonania kontraktu.

Weryfikacja transakcji polega na ustaleniu, czy zawiera ona tylko zaakceptowane produkty i czy odbywa się ona na rynkach dopuszczonych do handlu. Bada się także, czy osoby realizujące transakcję posiadają wymagane upoważnienia i nie przekraczają otrzymanego mandatu.

Po zawarciu kontraktu, middle office powinien niezwłocznie zweryfikować poprawność wprowadzonych do systemu danych kontraktu, także potwierdzeń stron 


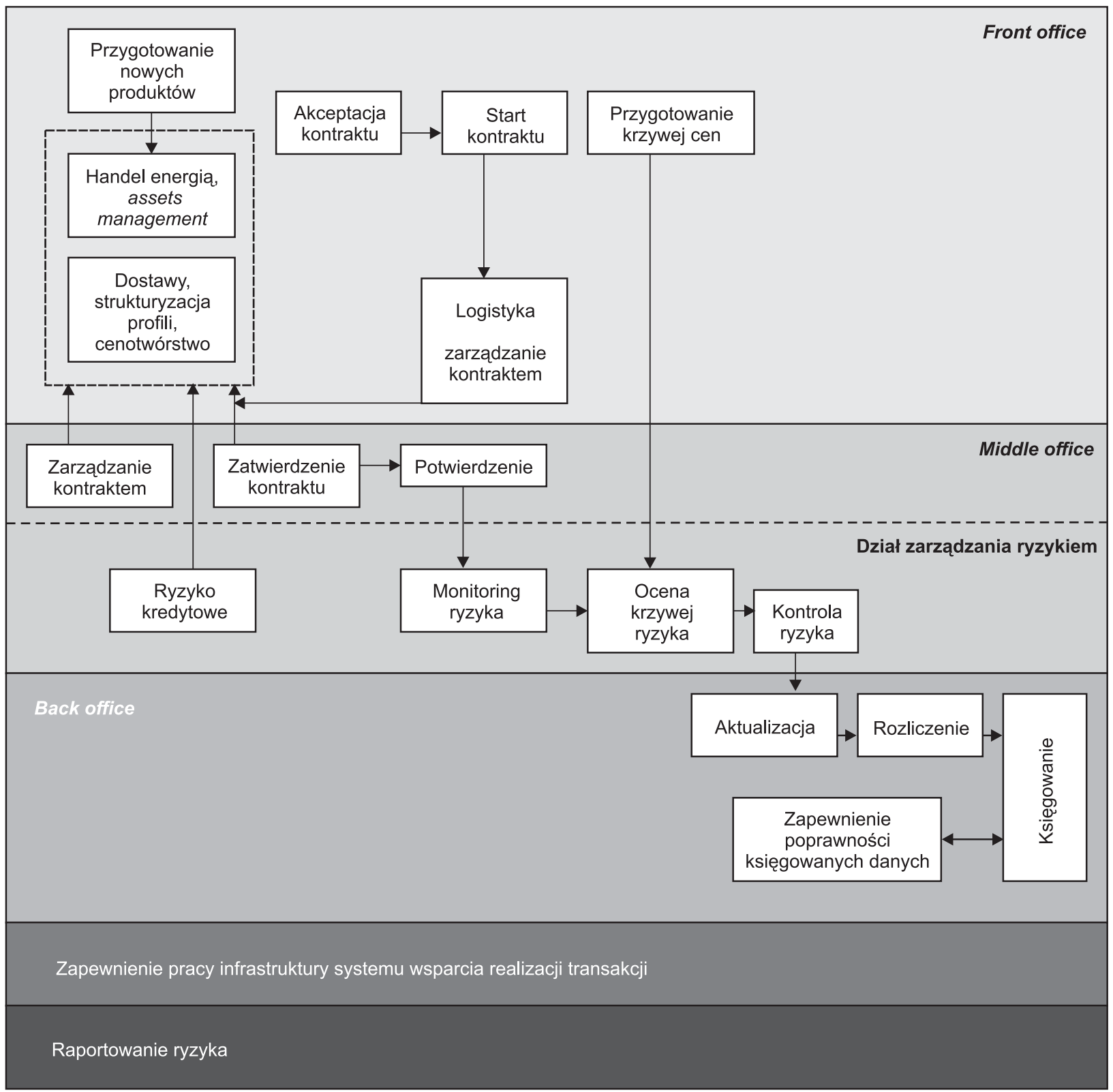

\section{Rys. Cykl realizacji transakcji na rynku energii elektrycznej}

Źródło: opracowanie własne na podstawie Governance and Controls, Committee of Chief Risks Officers, CCRO 2002, s. 17.

trzecich oraz dokonanych analiz ryzyka. Od tej pory middle office przejmuje podstawową funkcję kontrolną w realizacji transakcji. Dodatkowo komórki organizacyjne odpowiedzialne za kontrolę ryzyka kredytowego oraz administrację kontraktami powinny stale monitorować realizacje kontraktu w czasie jego trwania, aby zapewnić utrzymanie właściwego poziomu dostaw oraz zabezpieczenia ryzyka kredytowego.

W momencie, gdy kontrakt zostanie zakończony i wszystkie zobowiązania wypełnione, back office dokonuje jego rozliczenia (rozliczanie niezgodności i fakturowanie kontrahentów) i księgowania. Przed dokonaniem rozliczenia $\mathrm{z}$ klientem należy jeszcze przeprowadzić aktualizację danych tak, aby dane na fakturze były zgodne ze stanem rzeczywistym. Wszelkie rozbieżności powinny zostać wyjaśnione przez personel front office. Aktualizacja powinna być przeprowadza- na niezależnie od samego procesu wykonywania transakcji oraz jej logistyki. Back office odpowiedzialne jest również za płatność, co powinno być realizowane niezależnie od pozostałych czynności.

Efektywnie zaprojektowana organizacja procesu zarządzania realizacją transakcji handlowych powinna zagwarantować:

- skuteczność mechanizmu kontrolnego,

- efektywną wymianę informacji pomiędzy kierownictwem a służbami operacyjnymi,

- efektywną wymianę danych w ramach jednego poziomu organizacyjnego,

- przejrzystość odpowiedzialności,

- poufność danych i raportów.

Middle office prowadzi codzienny monitoring pozycji, dbając o to, aby każda indywidualna transakcja miała swoje odzwierciedlenie w profilu ryzyka. Pod- 
stawowym narzędziem wykorzystywanym do oceny ryzyka transakcji jest krzywa cen. Middle office weryfikuje przygotowaną przez front office krzywą cenowa na podstawie własnych niezależnie pozyskanych informacji z rynku. Proces kontroli i analizy ryzyka składa się z następujących czynności:

- codzienna ocena zrealizowanego i nie zrealizowanego wyniku oparta na wycenie mark-to-market,

- szacowanie ryzyka oparte na takich miarach, jak VaR, PaR, czy C-FaR ${ }^{6}$,

- analizy wrażliwości,

- stress testing ${ }^{7}$,

- ocena ryzyka płynności.

Do zadań zarządzania ryzykiem w zakresie zawieranych transakcji handlowych należy także ocena ryzyka kredytowego. Polega ona na sprawdzeniu, czy nie zostały przekroczone indywidualne limity kredytowe przedsiębiorstw i handlowców oraz globalny limit przedsiębiorstwa.

W przypadku przekroczenia jakiegokolwiek limitu, właściwe służby informują o tym osoby odpowiedzialne za to ryzyko oraz kierownictwo firmy. Nadzorują one jednocześnie przeprowadzenie działań korygujących.

Ryzyko kredytowe należy badać indywidualnie dla każdego kontrahenta. Może to jednak nie wystarczyć do uzyskania właściwego powiązania wyceny ryzyka kredytowego z aktualną sytuacją na rynku. Dodatkowym wsparciem powinna być analiza działalności handlowej każdego kontrahenta. Szczególnie ważne są informacje odnośnie do jakości zarządzania ryzykiem u kontrahenta oraz spójność jego działalności biznesowej z realizowanym procesem handlowym.

\section{Uwagi końcowe}

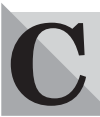

ałość istniejących kontraktów zakupu lub sprzedaży definiowana jest jako portfel (portfelem może też być otwarta pozycja ${ }^{8)}$ ). Portfel zawiera informacje o pozycji przedsiębiorstwa, które są niezbędne do obliczenia ekspozycji na ryzyko. Każda transakcja, zawarta na podstawie zmieniających się warunków rynkowych, prowadzi do zmiany wartości portfela i poziomu jego ryzyka. Na wartość ekspozycji wpływają również zewnętrzne czynniki, opisywane za pomoca danych rynkowych (np. płynność rynku, zmienność cen).

Służby zarządzania ryzykiem powinny zapewniać codzienny przegląd ryzyk oraz dostarczanie informacji o ich poziomie. Proces ten obejmuje następujące elementy:

- monitorowanie pozycji,

- aktualizowanie pozycji o zawarte kontrakty,

- szacowanie poziomów ryzyka,

- przygotowywanie odpowiednich raportów do kierownictwa firmy.

Zarządzanie ryzykiem powinno dotyczyć zagrożeń specyficznych dla rynku, na którym funkcjonuje przedsiębiorstwo, czasu dokonywanych operacji oraz przewidywanych kierunków rozwoju firmy. Analiza ryzyk ma na celu określenie ich hierarchii, dokonanie oceny prawdopodobieństwa ich wystąpienia oraz wielkości zasobów finansowych pozwalających na przetrwanie przedsiębiorstwa wobec niekorzystnego wpływu ryzyka. Wykorzystanie metod matematycznych powinno umożliwić określenie aktualnej wartości ryzyka ${ }^{9}$. Wynikiem powyższej oceny jest specyfikacja narzędzi, które powinny przynajmniej ograniczyć negatywny wpływ poszczególnych zagrożeń na sytuację finansową przedsiębiorstwa.

dr Dariusz Michalski Grupa Kapitałowa GZE

\section{PRZYPISY}

1) Podobnie należy postępować $\mathrm{w}$ przypadku wprowadzania do obrotu nowych produktów. Za każdym razem należy ocenić, czy profil ryzyka takiego produktu jest zgodny z polityką zarządzania ryzykiem i tolerancją firmy na ryzyko.

2) Opracować strukturę transakcji, scharakteryzować najważniejsze ryzyka oraz wycenić jej wartość.

3) Ceny są pozyskiwane z notowań brokerów, elektronicznych platform handlowych, publikacji energetycznych, analizy fundamentalnej przyszłych cen, technik prognostycznych oraz już zawartych kontraktów forward.

4) W długim i średnim okresie obejmuje niepewność co do przyszłej wielkości sprzedaży, w krótkim okresie zaś stanowi możliwość straty powstałej w wyniku braku dostawy zakontraktowanej ilości i zawiera w sobie zarówno ryzyko operacyjne, jak i wpływ czynników niepewnych, np. pogody.

5) Governance and Controls, Committee of Chief Risks Officers, CCRO 2002, s. 25.

6) Wartość narażona na ryzyko (VaR) to maksymalna kwota, jaką można stracić w wyniku inwestycji w portfel o określonym horyzoncie czasowym i przy założonym poziomie ufności. VaR definiuje się jako stratę, która z pewnym stopniem prawdopodobieństwa w określonym czasie nie zostanie przekroczona.

Miara określająca zysk narażony na ryzyko (PaR) szacuje, o jaką wielkość przyszłe zyski mogą być niższe od planowanych. Miara ta jest bezpośrednio powiązana z ryzykiem przyszłych wyników finansowych i dlatego znajduje zastosowanie w funkcjonowaniu jednostek realizujących fizyczna dostawe aktywów. $Z$ tego powodu PaR jest szczególnie interesujący dla przedsiębiorstw, które realizują nie tylko działania czysto spekulacyjne, lecz posiadają portfel kontraktów reprezentujący fizyczny przepływ towaru (np. zaopatrują klientów finalnych w energię elektryczną). PaR zakłada, że fizyczna pozycja nie zostanie zamknięta do momentu jej wykonania, co sprawia, że konieczne staje się uwzględnienie wszystkich czynników zagrażających sytuacji finansowej przedsiębiorstwa.

Przeptywy pieniężne narażone na ryzyko (C-FaR) można zdefiniować jako określone prawdopodobieństwo rozkładu przyszłych przepływów z działalności operacyjnej przedsiębiorstwa dla określonego czasu, ustalone na bazie dostępnych informacji. C-FaR jest miarą pokrewną do VaR. Analiza C-FaR dostarcza informacji do zidentyfikowania, czy przedsiębiorstwo w warunkach ekspozycji na ryzyko posiada niezbędne zasoby finansowe konieczne w celu zaspokojenia nieprzewidzianych płatności, realizacji koniecznych inwestycji, czy kontynuowania badań i rozwoju.

7) Stress testing umożliwia kierownictwu przedsiębiorstwa ocenę wpływu na pozycję finansową przedsiębiorstwa wybranych scenariuszy, opisujących zdarzenia na rynku i w otoczeniu przedsiębiorstwa, które powodują ekstremalne zmiany czynników ryzyka. Właściwie przeprowadzony stress test powinien charakteryzować się pewnym poziomem prawdopodobieństwa oraz wysokim poziomem przejrzystości, identyfikować kluczowe założenia testu i ich wpływ na czynniki ryzyka.

8) Portfel zbudowany jest z zasobów ekonomicznych - aktywów (zarówno materialnych, jak i niematerialnych), które mają przynieść firmie zysk.

9) Przykładem może być zastosowanie miary, jaką jest wartość narażona na ryzyko (VaR) do oceny ryzyka rynkowego. 